\title{
'n Prakties-teologiese ondersoek na die kerklike jaar in die prediking van die Nederduitse Gereformeerde Kerk
}

\author{
G Bothma (Polokwane) \\ Departement Praktiese Teologie \\ Universiteit van Pretoria
}

\begin{abstract}
A practical-theological investigation into the role of the church year in the liturgy and preaching of the Dutch Reformed Church

The aim of this article is to discuss the valuable role the church year can play in liturgy and preaching and the service and activities of the church. The article demonstrates that the rediscovery of the church year is one of the most remarkable aspects of the twentiethcentury reform and renewal of Christian worship. Within a context of poverty and continuing change, the church year - if valued positively and if accentuated in the preaching - could lead to the celebration of God.
\end{abstract}

\section{INLEIDING}

Die kerklike jaar is 'n belangrike hulpmiddel in die kommunikatiewe handelinge van die gemeente en behoort deur gemeentes benut te word: "Onder die primêre leiding en werking van die Heilige Gees, wil die kerklike jaar 'n belangrike hulpmiddel wees in die hande van predikers, kerkraadslede en lidmate om die groot strukture van die evangelie beter te volg en op 'n verantwoordelike en planmatige wyse die prediking en erediens in te rig tot opbou en versterking van sowel leraars as gemeente" (Barnard 1989:1; vgl 1954:34-37; Macleod 1981:117, 118). Buiten dat die kerklike jaar groot waarde inhou, is dit ook aktueel én is daar die afgelope tyd 'n hernieude en toenemende belangstelling daarin en 'n herwaardering daarvan (Saliers 1994:92). In gepubliseerde werke (vgl Adam 1980; Bieritz 1988, 1995; Webber (ed) 1994; Oskamp \& Schuman (reds) 1998; Schuman 1998, 2002) is daar ook reeds aangetoon dat die kerklike jaar 'n goeie raamwerk bied vir die liturgie, die prediking en die kerklike lewe en bediening in die algemeen.

\footnotetext{
*Hierdie artikel is gebaseer op 'n gedeelte van die PhD-proefskrif onder leiding van prof $\mathrm{dr}$ C J A Vos, getiteld, "'n Prakties-Teologiese ondersoek na die kerklike jaar in die prediking van die NG Kerk." Erkenning word ook verleen aan Prof Chris Smit (Departement Statistiek) en Me Elana Mauer (Departement Inligtingstegnologie) van die Universiteit van Pretoria.
} 
Hierdie waardering en belangstelling is ook plaaslik en binne die NG Kerk opmerklik (vgl bv BUVTON se Leesrooster vir lidmate gebaseer op die kerklike jaar en die NG Kerk in Oos-Transvaal se Woordwyser: 'n dag-tot-dag Bybelleesprogram). Die NG Kerk het ook in die onlangse verlede twee rigtinggewende besluite geneem met betrekking tot die kerklike jaar. Eerstens is artikel 48.4.1 van die Kerkorde (NG Kerk 1998:17) uitgebrei om te lui: "Met die oog op die verkondiging van die volle raad van God moet die prediking deurgaans volle reg aan die kerklike jaar en die belydenisskrifte laat geskied." Hiernaas het die sinode van 1998 aan die Algemene Kommissie vir Erediens opdrag gegee "om 'n studie te maak oor die funksie van 'n leesrooster vir die liturgie" (NG Kerk 1999:453; vgl 1998:253) en na aanleiding van die studie het die sinode in 2002 die voorgestelde werkswyse ten opsigte van 'n leesrooster in die liturgie goedgekeur, tesame met 'n verdere opdrag aan dieselfde kommissie om prakties hieraan gestalte te gee (NG Kerk 2003:538; vgl 2002:81-83).

\section{PROBLEEMSTELLING}

Ten spyte daarvan dat daar in bestaande werke genoeg grondige leiding aangebied word sodat ' $n$ teologiese basisteorie ten opsigte van die kerklike jaar en die benutting daarvan in die prediking ontwerp kan word, bestaan daar by al hierdie werke egter ' $n$ groot gaping ten opsigte van die praxis met betrekking tot die kerklike jaar in die prediking. Daar is ook nog nie empiries ondersoek ingestel na die stand van die kerklike praktyk ten opsigte van die kerklike jaar in die prediking nie. Indien dit waar is dat die kerklike jaar 'n belangrike plek in die prediking inneem en daar gapings ten opsigte hiervan in die kerklike praktyk bestaan, kan tekortkominge hierin lei tot 'n gedeeltelike disfunksionering in die prediking en ander kommunikatiewe handelinge van die gemeente. Naas die vraag of, en indien wel, hoe die kerklike jaar in die prediking ontgin kan en behoort te word, moet dus ook antwoorde gevind word op vrae soos: Wat gebeur presies ten opsigte van die kerklike jaar in die kerklike praktyk? Kom dit tuis in die praktyk? Indien wel, op watter wyse? Word daar bewustelik aandag geskenk aan die kerklike jaar in die prediking? Geniet al die vieringsgeleenthede op die kerklike kalender aandag, of is dit slegs sekere geleenthede wat aandag ontvang? Verder: Sal predikante bereid wees om op langtermynbasis voortdurend aandag te gee aan die kerklike jaar indien hulle riglyne daarvoor sou ontvang?

\section{METODE VAN DIE ONDERSOEK}

Aangesien die kennis oor die vraag of hierdie insigte en standpunte enigsins in die praktyk van die gemeente al grondgevat het gebrekkig is, is 'n 
ondersoek na die kerklike jaar in die prediking nodig. 'n Prakties-teologiese metodologie kan by wyse van literatuur- en empiriese studie onder andere help om die kerklike jaar beter te verstaan en om vas te stel hoedanig die kerklike jaar homileties ontgin kan en behoort te word. Dit kan langs hierdie weg help om verstellings aan te bring waar daar probleme in die praktyk bestaan. Die teorie en praxis met betrekking tot die kerklike jaar in die prediking word sodoende in 'n kreatiewe interaksie met mekaar in verband gebring (Zerfass 1974:164-169; vgl Dingemans 1990, 1994; Van der Ven 1993) sodat daar deur hermeneutiese, empiriese en strategiese aktiwiteit (Heitink 1993:159-163) tot 'n verbeterde praxis gekom kan word.

In hierdie artikel word dit gedoen deur die kerklike jaar nader te omskryf en te beskou en deur te bepaal hoedanig die momente in die kerklike jaar homileties ontgin kan word. Die praktyk van die kerklike jaar in die prediking van die NG Kerk word daarna ondersoek en voorstelle word gemaak m.b.t. 'n verstelde praxis van die kerklike jaar in die prediking.

\section{4. 'N NADERE OMSKRYWING VAN DIE KERKLIKE JAAR}

Die begrip kerklike jaar word vanselfsprekend en algemeen gebruik vir die "liturgiese verskynsel wat in die loop van die geskiedenis van die Christelike Kerk ontstaan het en wat geleidelik gegroei het tot sy huidige vorm" (Barnard 1954:9). Daar bestaan egter verskille oor die opvatting, wese, omvang, indeling, waarde en doel daarvan, veral aangesien dit binne verskillende kerklike tradisies op verskillende wyses funksioneer. Kernagtig is die kerklike jaar die "cyclus van de kerklijke feesten" (Achelis 1911:89) en kan dit dien as "a guide to spirituality and a textbook of theology ... a journey that follows the life of Christ and invites the worshiper to remember and sense the significance of dozens of scriptural events, persons and images"(Webber 1994:77, 79). As sodanig wil die kerklike jaar Christengelowiges uitdaag om die verstaan van hulle geloof te verdiep, hulle te verwonder oor die groot mag en liefde van God soos wat dit sigbaar word in Jesus Christus en hulle plek in die liggaam van Christus te vier en ook die kerk help om op betekenisvolle wyse haar lewe te oriënteer rondom die Persoon en werk van Jesus Christus as fokuspunt. Reeds hieruit blyk die waarde van die kerklike jaar duidelik.

Die naam "kerklike jaar" word verkies bo name soos kerkjaar, liturgiese jaar, die jaar van die/ons Here of Christusjaar en die jaar van heil/genade (vgl Achelis 1911:89; Barnard 1954, 1989; Pinsk 1963; Bieritz 1988:27; Verheul 1992:327), veral omdat dit reeds algemeen bekend is en omdat die kerklike jaar nie alleenlik met die liturgie, prediking of feesvieringe te doen het nie, maar ook met ander kommunikatiewe handelinge van die Christelike geloofsgemeenskap. Dit gaan in die kerklike jaar om 'n inhoudelik geslote, 


\section{'n Prakties-teologiese ondersoek na die kerklike jaar}

maar soepel sisteem wat opgebou is uit 'n bepaalde teologiese grondgedagte wat verband hou met die Christelike kerk en haar Here (vgl Verheul 1992:327). Dit staan nie teenoor die burgerlike jaar nie, maar gaan daarheen langs 'n eie weg. Die waarde van die kerklike jaar blyk verder daaruit dat dit benut kan word om 'n dieper betekenis van en belewenis aan die verloop van kalendertyd te verleen.

Die kerklike jaar handel oor die Christelike feeste - die hart van die kerklike lewe en werk - en bring hierdie feeste met alles wat daarmee saamhang en daardeur uitgedruk word, in die prediking en andersins, op sinvolle wyse aan die orde. Sodoende word die groot dade van God in herinnering geroep en laat dit die boodskap daarvan steeds opklink. Dit laat ook die lig van die Bybel val op hierdie gebeure en wat dit vir ons vandag beteken. In besonder laat dit ons die verlossingswerk en verlossingsgang van God, soos dit in die Persoon en werk van Christus tot openbaring gekom het en deur die Heilige Gees geëffektueer is, volg en daardeur aangespreek word. Deur elke fees word die groot heilsfeit wat dit herdenk se besondere waarheid verdig, verlewendig, verkondig en word diegene wat dit vier betrek en word die betekenis daarvan vir hulle lewens uitgespel en die heil daardeur vir hulle werksaam toegesê en beleef: "Die evangelie wil immers nie slegs vertaal, betuig en met woorde verkondig word nie. Dit wil gehoor, ter harte geneem en geleef word" (Barnard 1989:2; vgl Bohren 1973).

Die kern, oftewel die middelpunt of dieptepunt, van die hele heilsgeskiedenis - en daarom ook van die kerklike jaar - is die kruis en opstanding van Jesus Christus, wat as sodanig as 't ware die draaipunt van die geskiedenis van die mensheid is. Die kruis en opstanding van Christus kan egter nie los gesien word van sy geboorte, lyding en die verwagting van sy wederkoms nie. Op heilshistoriese vlak vestig die kerklike jaar dus die oog op die geheel, sodat God se heilshandelinge nie versplinter nie en funksioneer dit soos 'n spinneweb waarvan die verskillende drade heg saamgeweef is (Barnard 1989:3; Vos \& Pieterse 1997:148, 149). Volgens Bieritz (1988:26-27) dien die kerklike jaar in hierdie verband as weg waarlangs die gelowige sy tyd (chronos) binne die goddelike tyd/“Christuszeit" (kairos) beleef: "Das Kirchenjahr ist eine nötige, zutiefst menschliche Weise, die Christusgeshichte zu vergegenwärtigen und an ihr teilhaben zu lassen" (vgl ook Josuttis 1991:52-64).

\section{DIE OMVANG EN NADERE INVULLING VAN DIE KERKLIKE JAAR}

Rondom die groot heilsfeite het die viering van die Sondag asook drie siklusse van feeste (die kers-, paas- en pinkstersiklus) ontwikkel wat in die 
behandeling van die kerklike jaar bekendstaan as die kerksiklus en daarnaas het ook verdere ontwikkeling van 'n siklus rondom die tyd na Pinkster voorgekom wat hoofsaaklik gewy word aan "the mystery of Christ in all its aspects" (Adam 1992:282). Hierdie tydperk, wat vroeër as 'n verlengstuk van Pinkster beskou is (vgl Leonard 1994:209), word Ordinary Time (vgl bv Consultation on Common Texts 1992:14-15) genoem en Barnard (1989:12) verwys daarna as die feeslose helfte van die jaar. Die benaming Koninkrykstyd (= "Kingdomtide"; vgl Webber 1994:457-458) word egter hiervoor verkies, omdat die klem gedurende hierdie seisoen val op die verskillende maniere waarop die koninkryk van God sigbaar en tasbaar gemaak word in die kerk en in die wêreld. Koninkrykstyd kan ook as oorhoofse fokus dien om te help dat die Sondae in hierdie tyd nie as losstaande geleenthede beskou word nie, maar aan mekaar verbonde is. Die kerk-/feessiklus vier in hierdie verband die advent, aanbreek en vestiging van die koninkryk van God en Koninkrykstyd vier die verdere effektuering daarvan op alle terreine van die lewe (vgl Barnard 1989:9-13; Verheul 1992:326).

'n Enger beskouing van die kerklike jaar sou beskryf kon word as 'n meesterverhaal waarin drie hoofmomente voorkom: Kersfees, Paasfees en Pinkster. In elkeen van die narratologiese eenhede is daar sleutelgebeure wat afspeel, gebeure waarin God in en deur Jesus Christus die handelende Hoofkarakter is. Sy handelinge kan nie beperk word tot die krip en die kruis van Jesus nie en strek veel verder: ook verby die gawe van die Gees, want God werk deur sy Gees in mense en in sy wêreld. In God se verhaal word mense daarom deurgaans nie net verander om te wees wat hulle in Christus reeds is nie, maar ook betrek in die Godsverhaal en diensgeoriënteerde missiologie. In die "tussentyd", die koninkrykstyd, kan met behulp van "creatieve mogelijkheden" aan die spanning tussen die "reeds" en die "nog nie" van God se betrokkenheid by sy skepping in en deur die evangelie gestalte gegee word (Schuman 2002:116).

Juis om hierdie rede word 'n ruimer opvatting van die kerklike jaar, wat God en die evangelie tot diens kan wees, verkies. Dinamiese omgang met die kerklike jaar kan die gemeente en die prediker in staat stel om nie net, naas die festa Domini, op verantwoordelike wyse aan te sluit by nadere invullings in die kerklike jaar wat vir die situasie relevant is nie, maar om ook op kreatiewe wyse die teologiese lading van die bepaalde moment(e) in die kerklike jaar konkreet in die praxis te laat kommunikeer. Uit die aard van die saak kan enigiets en alles nie net so aanvaar word nie en sal diegene wat hiermee werk in die gemeente of in die kerk in breë ' $n$ verantwoordelike werkswyse moet bepaal wat konsekwent toegepas word. Veel kan daarom geleer word van kerke wat reeds op weg gegaan het hiermee. 
Die volgende primêre inskrywings in die kerklike jaar kan as vertrekpunt dien by die nadere invulling van 'n kerklike kalender:

\begin{tabular}{|c|c|}
\hline SIKLUS & PRIMÊRE INSKRYWING OP SONDAG \\
\hline Adventtyd & Eerste tot Vierde Sondag in Advent \\
\hline Kerstyd & $\begin{array}{l}\text { Kersfees } \\
\text { Sondag / Sondae na Kersfees }\end{array}$ \\
\hline Epifanietyd & $\begin{array}{l}\text { Epifaniefees } \\
\text { Eerste tot Sesde Sondag na Epifanie } \\
\text { Verheerliking- / Transformasiesondag }\end{array}$ \\
\hline Lydenstyd & $\begin{array}{l}\text { Eerste tot Sesde Sondag in Lydenstyd } \\
\text { Palm- / Passiesondag }\end{array}$ \\
\hline Paastyd & $\begin{array}{l}\text { Paasfees / Paas- / Opstandingsondag } \\
\text { Tweede tot Sesde Sondag in Paastyd }\end{array}$ \\
\hline Hemelvaart & Sondag na Hemelvaart \\
\hline Pinkstertyd & $\begin{array}{l}\text { Pinkstersondag / -fees } \\
\text { Drie-eenheid- / Triniteitsondag / -fees }\end{array}$ \\
\hline Koninkrykstyd & $\begin{array}{l}\text { Eerste tot Twee en twintigste Sondag in } \\
\text { Koninkrykstyd }\end{array}$ \\
\hline & Christus die Koning - Sondag \\
\hline
\end{tabular}

Tabel 1: Primêre vierings in die kerklike jaar

Naas hierdie Sondae, is Kersfees, Aswoensdag, die Heilige/Groot Lydensweek (waarby Goeie Vrydag ingesluit word) en Hemelvaart ook van primêre belang en indien 'n ruimer beskouing van die kerklike jaar gehuldig word, kan daar op 'n uitkringende basis verdere invulling gedoen word. Verskillende inskrywings kan gedoen word afhangende van die omvang van die beskouing van die kerklike jaar wat gehuldig word. Die sogenaamde kleiner Christologiese vierings (bv die Naamgewing van Jesus) beskik oor "evangelical values that we are just beginning to discover" (White 2000:69) en kan sonder veel oorweging saam met ander besondere dae wat verband hou met Jesus se lewe en leer by die "klassieke inskrywings" gevoeg word. Hiernaas kan vieringsgeleenthede rondom die sogenaamde heiliges en ander Bybelse figure, soos by ander tradisies, met omsigtigheid ingesluit word (Schuman 1998:450-453). Wanneer uit besondere (Son)dae keuses gemaak word, moet daar onderskei word tussen dae wat vir die breë kerklike wêreld van belang is (bv Hervormingsdag op die laaste Sondag van Oktober en die 
Wêreldbiddae vir Vroue en vir Mans, afsonderlik op die eerste Vrydag en Saterdag van Maart) en dae wat vir plaaslike kerke van belang is (bv Versoeningsdag/Geloftedag op 16 Desember en spesifiek benoemde Sondae, soos Arbeidsondag op die Sondag die naaste aan 1 Mei / Werkersdag).

Aangesien die gereformeerde teologie die kerk en staat in verwantskap met mekaar beskou en omdat die NG Kerk (2003:492) "tot 'n konstruktiewe verhouding met die staat van die land waarin ons woon" verbind is, bly dit 'n ope vraag of dae wat vir die burgerlike samelewing as belangrik uitgesonder word nie ook vir die kerk as besondere dae uitgelig moet word nie. Die redes wat veral die NG Kerk in die verlede rondom Geloftedag aangevoer het vir die insluiting van hierdie dag in die kerklike kalender (vgl bv Du Toit 1969:27-29; NG Kerk 1990:115; 1995:436, 572), kan goedskiks - al is dit dalk slegs deur Christene met ander oortuigings as Afrikaner-Christene - vir ten minste sommige van die dae wat tans as openbare vakansiedae beskou word, aangevoer word. Die feit dat die oorgang na die demokratiese bestel hier te lande relatief vreedsaam geskied het, word deur baie as 'n Goddelike ingrype en wonderwerk beskou. Dit is veral so omdat hierdie oorgang sonder 'n burgeroorlog, soos wat dit in baie ander Afrikalande gebeur het, plaasgevind het. Om dieselfde redes kan internasionale gedenkdae wat raakvlakke het met die missio Dei en die dienswerk van die kerk (bv Wêrelddag vir die beëindiging van Rassediskriminasie op 21 Maart) en "nie-amptelike feesdae", wat in elk geval sekulêr en deur lidmate van die kerk gevier word, maar ook veel met die lewe en etiek van Christene te doen het (bv Moedersdag op die tweede Sondag in Mei) ook in aanmerking geneem word.

Sondae waarop die sakramente bedien word behoort 'n hoë prioriteit in die kalender van die gemeentelike lewe te hê aangesien dit verband hou met die gemeente se verbondsbelewenis (vgl Vos \& Pieterse 1997:168-182; Vos 1996:290-293). Hiernaas is belangrike momente in die verloop van die kerklike jaar vir die gemeentelike lewe ten minste die gemeente se verjaardagviering, die bevestiging van ampsdraers, en openbare belydenisaflegging. Volgens Mouw (1994:82) neem gemeentes - bewustelik of onbewustelik - ten minste ses "kerklike jare" in ag wanneer hulle hulle werksaamhede beplan en hulle kalenders opstel. Hy onderskei die volgende: 'n "lectionary year" (waarin erediensbeplanning uiteengesit word), 'n "catechism year" (waarin die patroon van die Sondae in die Heidelbergse Kategismus gevolg word), 'n "hallmark year" (waarin dae soos Moeders-, Vaders- en Valentynsdag en ander spesiale geleenthede wat op een of ander wyse deur gemeentes in ag geneem word), 'n "denominational programs year" (waarin bv Sending- en Wêreldhongersondag ens verreken word),'n "local congregational activities year" (waarin bv die bevestiging van 


\section{'n Prakties-teologiese ondersoek na die kerklike jaar}

kerkraadslede in ag geneem word) en 'n "civic holiday year" (wat aspekte van die burgerlike jaar verreken) (vgl ook Schuman 2002:129-130; White 1989:7576).

Wanneer predikers of gemeentes die kerklike jaar nader invul, bly dit belangrik om die Sondag as primêre vieringsdag te handhaaf en om alle geleenthede wat oorweeg word vir inagneming in 'n eie kerklike kalender, te weeg aan die vraag of dit verband hou met die wese en betekenis van die Sondag. Leesroosters, as vasgestelde versamelings van lesings of geselekteerde gedeeltes uit die Skrif, wat gerangskik en bedoel is vir die verkondiging en liturgiese gebruik in die aanbidding van God se mense deur die loop van die kerklike jaar (maar veral op spesifieke Sondae), is waardevolle hulpmiddels in die bevordering van die kommunikatiewe handelinge in diens van die evangelie (vgl CCT 1992:9; NG Kerk 2002:81). Die kerklike jaar - en leesroosters wat hiermee verband hou - kan ook daartoe bydra dat gemeentes nie uitgelewer is aan die willekeur van predikante of groepe wat die prediking bepaal nie én dat die prediking aktueel is (vgl Barnard 1989:1; Macleod 1981:114; Pieterse 2001 :ix; Vos 1988:220).

\section{HOMILETIESE TOESPITSING}

Die ontwikkeling en groei van die kerklike jaar tot in sy huidige gestalte het geskied in 'n wisselwerking tussen die Bybelse teks, kerklike tradisie en die konteks van die geloofsgemeenskap. Die invloed wat die omgewing op die kerklike jaar gehad het, is veral duidelik te bespeur in geleenthede soos Kersfees, wat bedoel is as 'n alternatiewe vieringsgeleentheid vir die heidense fees van "die geboorte van die Onoorwinbare Son" (= die natale solis invicti, met verwysing na Jupiter en ter ere van Mitras) wat deur keiser Aurelianus vir die hele Romeinse Ryk ingestel is na sy oorwinning oor die hoofstad van Sirië in 274. Toe die Christendom die gevestigde godsdiens van die Romeinse Ryk geword het, is hierdie heidense fees met die Kersfees (ook genoem die "Christusfees") vervang (Bieritz 1988:197-202; Wegman 1985:104-105). Epifanie, die oorspronklike viering van Jesus se geboorte, is dan ook langs hierdie weg deur die westerse kerk verdring (vgl Van der Leeuw 1946:97).

Wanneer die inskrywings in die kerklike jaar homileties ontgin word, is dit belangrik om die ontwikkeling daarvan te verreken en om op die kerugmatiese intensie daarvan te fokus. By elkeen van die vieringsgeleenthede moet die kontinuïteit wat dit het met die Bybelse inhoude waaruit dit voortgevloei het gehandhaaf word, terwyl die diskontinuïteit wat bestaan deeglik verreken moet word. Daar kan oor of met of met die oog op die geleentheid in die kerklike jaar gepreek word en "'Preaching the Church Year' is not simply a question of determining the seasonal context and theme of the 
day. A far more complex and dynamic relationship between preaching and the liturgical year may be detected, especially in understanding the origins of the year (Eslinger 1995:76-78).

Onverantwoordelikheid hierin kan lei tot disfunksie in die prediking. Hiermee saam is dit belangrik dat dit in die kerklike jaar in die prediking nie maar gaan om die oorvertel van 'n betrokke moment in die evangelie asof dit 'n historiese gebeurtenis in die verlede is nie:

... the Gospel cannot be reduced to historical observance. To do so is to destroy it. Christ is not some historical person who once lived and died and whom we now respectfully remember. He is a presently living Lord, a Lord who demands discipleship in the present, not relegation to the safe distance of the past.

(Westerhoff \& Willimon 1980:58)

Die uitdaging is daarom om die wesenlike van die betrokke geleentheid deur die prediking teenwoordig te stel in die hede. Waar dit gedoen word, blyk die waarde van die kerklike jaar duidelik.

Dit is te begrype dat binne die bestek van hierdie artikel nie op die ontginningsmoontlikhede van elkeen van die inskrywings in die kerklike jaar ingegaan kan word nie (vgl Bothma 2004:191-259 hiervoor). Dit is wel definitief so dat die kerklike jaar groot waarde vir die prediking van die NG Kerk kan inhou en dat dit ' $n$ struktuur daaraan kan verleen en ook raakvlakke bied om liturgiese en ander gemeentelike aktiwiteite te inisieer en aan te moedig. Die kerklike jaar kan verder help dat daar oor sake gepreek word wat nie andersins in die kerk aan die orde sou kom nie. Die verwagting van God se koninkryk (Advent), die koms (Kersfees) en verskyning (Epifanie) van God in ons midde, asook die lyding en sterwe (Lydenstyd) en die oorwinning van ons Here oor die dood (Opstandingstyd), sy hemelvaart, die viering van die Gees (Pinkster) en die voortgaande vestiging van die koninkryk (Koninkrykstyd), is vandag nog aktueel en moet ontgin en ontplooi word.

\section{DIE KERKLIKE JAAR IN DIE PREDIKING VAN DIE NG KERK}

'n Empiriese ondersoek wat met verwysing na die prediking gedurende 2002/2003 in die NG Kerk onderneem is, het bruikbare inligting in verband met die kerklike jaar in die prediking van die NG Kerk opgelewer. Hierdie kwantitatiewe komponent van die ondersoek is gedoen by wyse van 'n toegespitste posvraelys wat aan predikante van die NG Kerk gestuur is. Die totaal van die predikante in die NG Kerk aan die begin van 2003 (vgl Jaarboek 
van NG Kerke 2003:5, 363-365), is na die volgende eenheidsgetal afgerond en 'n steekproef van 400 is uit die populasie van 1,200 (afgerond) getrek ooreenkomstig 'n sistematiese, ewekansige bepaling waarin elke populasieelement 'n gelyke kans gehad het om getrek te word (vgl Steyn, Smit \& Du Toit 1984:18). Die data wat vervat is in die 196 vraelyste $(=10,68 \%$ van die populasie) wat teen die keerdatum ontvang is, is deur die Departement Rekenaarondersteuning van die Universiteit van Pretoria vasgelê en met die hulp van die Departement Statistiek, Universiteit van Pretoria, geïnterpreteer (vgl Bothma 2004:266-268). Die betroubaarheid en die geldigheid van die ondersoek is ook hierdeur verder verseker.

Uit dié ondersoek het dit onder andere geblyk dat die kerklike jaar se primêre inskrywings (soos Kersfees, Paasfees en Pinkster) en ander belangrike vieringsgeleenthede (soos Hervormingsondag) 'n beduidende invloed op die prediking het, maar dat daar ook geleenthede is wat nie deel uitmaak van 'n enger beskouing van die kerklike jaar nie (soos Moedersdag), wat 'n groter invloed op die prediking het as ander belangrike geleenthede (soos Drie-eenheidsondag). Die invloed wat die primêre inskrywings in die kerklike jaar en enkele ander belangrike en gevestigde vierings op die tekskeuse en prediking gehad het, kan soos volg weergegee word:

\begin{tabular}{|c|c|c|c|c|c|}
\hline \multirow[t]{2}{*}{ INSKRYWING } & \multirow[t]{2}{*}{$\mathbf{N}$} & \multicolumn{2}{|l|}{ JA } & \multicolumn{2}{|c|}{ NEE } \\
\hline & & $\mathbf{f}$ & $\%$ & $\mathbf{f}$ & $\%$ \\
\hline Epifanie & 194 & 127 & 65.46 & 67 & 34.54 \\
\hline $\begin{array}{l}\text { Al die of enige van die Sondae } \\
\text { in Lydenstyd (uitgesluit } \\
\text { Verheerlikingsondag) }\end{array}$ & 192 & 183 & 95.31 & 9 & 4.69 \\
\hline Verheerlikingsondag & 193 & 129 & 66.84 & 64 & 33.16 \\
\hline Paasfees / Opstandingsondag & 196 & 191 & 97.45 & 5 & 2.55 \\
\hline $\begin{array}{l}\text { Al die of enige van die Sondae } \\
\text { in Paastyd }\end{array}$ & 195 & 189 & 96.92 & 6 & 3.08 \\
\hline Pinkstersondag & 196 & 182 & 92.86 & 14 & 7.14 \\
\hline $\begin{array}{l}\text { Drie-eenheidsondag (Sondag } \\
\text { Trinitatis) }\end{array}$ & 194 & 101 & 52.06 & 93 & 47.94 \\
\hline Hervormingsondag & 196 & 183 & 93.37 & 13 & 6.63 \\
\hline Christus die Koning - Sondag & 194 & 104 & 53.61 & 90 & 46.93 \\
\hline $\begin{array}{l}\text { Al die of enige van die Sondae } \\
\text { in Advent }\end{array}$ & 196 & 190 & 96.94 & 6 & 3.06 \\
\hline Kersfees & 195 & 187 & 95.9 & 8 & 4.1 \\
\hline Moedersdag & 194 & 107 & 55.15 & 87 & 44.85 \\
\hline
\end{tabular}

Tabel 2: Prediking en spesifieke inskrywings in die kerklike jaar

Epifanie, Verheerliking-, Drie-eenheid- en Christus die Koning-Sondag het op minder as sewentig persent (138 uit 196) van die respondente se tekskeuse en prediking 'n effek gehad. Die invloed wat Christologiese dae en dae wat 
verband hou met bybelse figure (spesifiek Maria en Johannes) het is nog minder. Die invloed van die nasionale vieringsdae het ook nie ' $n$ beduidende invloed op die tekskeuse en prediking nie en gewilde biddae (bv die Biddag vir Opvoeding en Onderwys, Wêreldbiddag en Sinodale Dank- en Biddag) het slegs ongeveer vyftig persent van die respondente se tekskeuse en prediking beïnvloed. Die geleentheid wat deur hierdie inskrywings gebied word om verskeie belangrike aksente wat in die prediking na vore gebring behoort te word, gaan dus grootliks by die respondente - en daarom ook die hoorders verby. Dit dui op 'n disfunksie met betrekking tot die kerklike jaar in die prediking van die NG Kerk. 'n Verbetering ten opsigte van die praxis kan moontlik bewerkstellig word deur aan te hou om die primêre inskrywings op die kerklike kalender te beklemtoon, maar tegelykertyd ook ander inskrywings op stelselmatige wyse bekend te stel en te benadruk.

Geleenthede soos die bediening van die sakramente, openbare belydenisaflegging en die bevestiging van kerkraadslede het almal 'n groot invloed (meer as $80 \%$ ) op die respondente se tekskeuse en die prediking gehad, maar wanneer hierdie geleenthede met inskrywings van die kerklike jaar saamgeval het, het dié geleenthede meermale voorkeur geniet bo die inskrywings van die kerklike jaar. Dit was slegs anders ten opsigte van die gemeente se verjaardag. Alhoewel amper veertig persent van die respondente aangedui het dat hierdie geleentheid hulle tekskeuse en prediking beïnvloed het, het byna tagtig persent van hulle voorkeur aan die geleentheid in die kerklike jaar waarmee dit saamgeval het, verleen. Die praxis kan verbeter word deur beplanning om belangrike geleenthede in die kerklike jaar en die gemeentelike lewe en arbeid met mekaar te koördineer.

Uit die ondersoek is dit duidelik dat die houding van predikante jeens die kerklike jaar 'n beduidende invloed het op die wyse waarop die kerklike jaar in die praktyk van die prediking gestalte vind. Dit is egter 'n geringe persentasie van die respondente $(0.51 \%)$ wat nie positief is jeens die kerklike jaar nie. Dit blyk ook dat nie al die predikers van die NG Kerk bereid is om op 'n langtermynbasis voortdurend in die prediking aandag te gee hieraan indien hulle behoorlike riglyne hiervoor sou ontvang nie. Meer as negentig persent van die respondente is wel bereid om dit te doen en $13.27 \%$ van die respondente het aangedui dat hulle kennis oor die kerklike jaar nie goed is nie. Op weg na 'n verbeterde praktyk ten opsigte van die kerklike jaar in die prediking van die NG Kerk, is dié erkenning en bereidwilligheid 'n helpende faktor waarby vorentoe aangesluit kan word.

Deur aan te sluit by die verskillende aksente van die kerklike jaar kan predikers - sonder geforseerdheid - nie net die hooflyne van die bybelse materiaal homileties ontgin nie, maar ook uitkom by dinge wat in die prediking 


\section{'n Prakties-teologiese ondersoek na die kerklike jaar}

aangeraak moet word, maar nie sonder bewustelike aandag daaraan onder die loep geneem sou word nie. Om enigsins te kan verander, is sekuriteit nodig (Brock \& Solerno 1994:5-31). Aangesien die primêre inskrywings op die kerklike kalender reeds sterk figureer in die prediking (vgl Tabel 2), kan die geleentheid wat hierdie inskrywings bied om sekuriteit te verleen aan hoorders met albei hande aangegryp word. Hierna kan beweeg word in die rigting van noodsaaklike veranderinge. Verandering in die prediking is veral nodig om die konteks van armoede te betrek. Lydenstyd en Advent is by uitstek geskik hiervoor en aangesien dit uit die empiriese ondersoek blyk dat dié momente in die kerklike jaar die prediking grootliks beïnvloed (albei meer as $95 \%$ ), kan groter doelgerigtheid hierin positiewe gevolge op die praxis hê.

\section{KONKLUSIE}

Al bestaan daar 'n gedeeltelike disfunksionering ten opsigte van die praxis met betrekking tot die kerklike jaar in die prediking van die NG Kerk, is daar heelwat positiewe tendense wat blyk uit die empiriese ondersoek. Meer as vyftig persent van die respondente maak reeds gereeld of soms gebruik van leesroosters wat met die kerklike jaar verband hou (veral die RCL en Woordwyser) en daar bestaan ook ' $n$ behoefte aan begeleiding ten opsigte van die praktyk van die kerklike jaar in die prediking en ander gemeentelike aktiwiteite. Die kerklike jaar kan in die prediking van die NG Kerk benut word en daar bestaan reeds 'n basis waarop voortgebou kan word. 'n Positiewe waardering van die kerklike jaar in die prediking, 'n groter klem daarop en 'n bewustelike verrekening van die konteks waarbinne die prediking voltrek word, kan lei tot 'n verbetering van die kommunikatiewe handelinge van gemeentes in diens van die evangelie. Die goeie nuus verdien om regdeur die jaar en genuanseerd gevier te word.

\section{Literatuurverwysings}

Achelis, E C 1911. Lehrbuch der Praktische Theologie, I-III.

Adam, A 1980. Das Kirchenjahr mitfeiern: Seine Geschichte und seine Bedeutung nach der Liturgieerneuerung. Freiburg: Herder Verlag.

Adam, A 1992. Foundations of liturgy: An introduction to its history and practice. Minnesota, MN: Liturgical Press.

Barnard, A C 1954. Die pinksterfees in die kerklike jaar. Kampen: Kok.

Barnard, A C 1989. Die kerklike jaar in diens van die prediking en liturgie, in Barnard, A C (red), Die jaar van God se genade: Gestaltes van woordbediening volgens die kerklike jaar, 1-19. Pretoria: NG Kerkboekhandel.

Bieritz, K-H 1988. Das Kirchen Jahr: Feste, Gedenk- und Feiertage in Geschichte und Gegenwar, 2. Aufl. München: Verlag $\mathrm{C} \mathrm{H}$ Beck.

Bieritz, K-H 1995. Das Kirchenjahr, in Schmidt-Lauber, H-C \& Bieritz, K-H (Hrsg), Handbuch der Liturgiek: Liturgiewissenschaft in Theologie und Praxis der Kirche, 453-489. Göttingen: Evangelische Verlaganstalt Vandenhoeck \& Ruprecht. 
Dingemans, G D J 1990. De tijd van de verborgen God: Verkenningen en Reflecties. 's Gravenhage: Boekencentrum.

Bohren, R 1973. Fasten und Feieren. Neukirchen: Neukirchener Verlag.

Bothma, G 2004. 'n Prakties-teologiese ondersoek na die kerklike jaar in die prediking van die Nederduitse Gereformeerde Kerk. Ph D Proefskrif, Universiteit van Pretoria.

Brock, L R \& Solerno, M A 1994. The interchange cycle: The secret to getting through life's difficult changes. Virginia, VA: Bridge Builder Media.

Consultation on Common Texts 1992. The Revised Common Lectionary 1992: The report from the consultation on common texts. Nashville, TN: Abingdon Press.

Dingemans, G D J 1994. Praktische Theologie: Geschiedenis, Theorie, Handelingsvelden, in Praktische Theologie 1994, 92-99. Zwolle: Waanders Uitgevers.

Du Toit, H D A 1969. Laat ons dan feesvier: 'n Oorsig van ons Christelike feesdae. Kaapstad: NG Kerk Uitgewers.

Eslinger, R L 1995. Church year and preaching, in Willimon, W H \& Lischer, R (eds), Concise encyclopedia of preaching, 1st edition, 74-78. Louisville, KY: John Knox.

Heitink, G 1993. Praktische Theologie: Geschiedenis, Theorie, Handelingsvelden. Kampen: Kok.

Jaarboek van die Nederduitse Gereformeerde Kerke. 2003. Jaargang 154. Tygervallei: Tydskriftemaatskappy van die NG Kerk.

Josuttis, M 1991. Der Weg in das Leben: Eine Einführung in den Gottesdienst auf verhaltenswissenschaftlicher Grundlage. München: Chr. Kaiser.

Kerkorde van die NG Kerk met reglemente en besluite van kerkregtelike aard soos vasgestel deur die Algemene Sinode in Oktober 1998. Wellington: HugenoteUitgewers.

Leonard, R C 1994. Biblical foundations of Christian festivals: Ascension, in Webber, R E (ed), The Biblical foundations of Christian worship: The complete library of Christian worship, Vol 1, 207-208. Star Song Publishing Group.

Macleod, D 1981. Presbyterian worship: Its meaning and method, new rev ed. Atlanta, GA: John Knox.

Mouw, R J 1994. The problem of the civil year in worship in Webber, R E (ed), The services of the Christian year: The complete library of Christian worship, Vol 5. Star Song Publishing Group.

Nederduitse Gereformeerde Kerk 1990. Agenda vir die agtste vergadering van die Algemene Sinode van die Nederduitse Gereformeerde Kerk. Pretoria:

Algemene Sinodale Kommissie van die NG Kerk.

Nederduitse Gereformeerde Kerk 1995. Handelinge van die negende vergadering van die Algemene Sinode van die Nederduitse Gereformeerde Kerk. Pretoria: Algemene Sinodale Kommissie van die NG Kerk.

Nederduitse Gereformeerde Kerk 1998. Agenda vir die tiende vergadering van die Algemene Sinode van die Nederduitse Gereformeerde Kerk. Pretoria: Algemene Sinodale Kommissie van die NG Kerk.

Nederduitse Gereformeerde Kerk 1999. Handelinge van die tiende vergadering van die Algemene Sinode van die Nederduitse Gereformeerde Kerk. Pretoria: Algemene Sinodale Kommissie van die NG Kerk. 
Nederduitse Gereformeerde Kerk 2002. Agenda vir die elfde sitting van die Algemene Sinode van die Nederduitse Gereformeerde Kerk. Pretoria: Algemene Sinodale Kommissie van die NG Kerk.

Nederduitse Gereformeerde Kerk 2003. Handelinge van die elfde sitting van die Algemene Sinode van die Nederduitse Gereformeerde Kerk. Pretoria: Algemene Sinodale Kommissie van die NG Kerk.

Pieterse, H J C 2001. Prediking in 'n konteks van armoede. Pretoria: Universiteit van Suid-Afrika.

Pinsk, J 1963. Gedanken zum Herrenjahr, Heruitgave. Mainz: Th. Schnitzler.

Saliers, D E 1994. How the practice of the Christian year affects congregational life, in Webber, R E (ed), The services of the Christian year: The complete library of Christian worship, Vol 5. Star Song Publishing Group.

Schuman, N A 1998. Getijden, in Oskamp, P \& Schuman, N A (eindreds), De weg van de Liturgie: Tradities, achtergronden, praktijk. 2de druk. Zoetermeer: Meinema.

Schuman, N A 2002. Jaarorde en leesorde: Karakteristiek en kritische vragen, in Barnard, M \& Schuman, N A (eindreds), Nieuwe wegen in de Liturgie, 115132. Zoetermeer: Meinema.

Steyn, A G W, Smit, C F \& Du Toit, S H C 1984. Moderne statistiek vir die praktyk. 3de uitgawe. Pretoria: $J \mathrm{~L}$ van Schaik.

Van der Leeuw, G 1946. Liturgiek. Nijkerk: Callenbach.

Van der Ven, J A 1993. Ecclesiologie in context. Kampen: Kok.

Verheul, A 1992. Het liturgisch jaar: Van de geshiedenis naar de theologie, in Tijdschrift voor Liturgie 76, 326-342.

Vos, C J A 1988. Spiritus sanctus: viator et triumphator, in Wethmar, C J \& Vos, C J A (reds), 'n Woord op sy tyd: 'n Teologiese feesbundel aangebied aan professor Johan Heyns ter herdenking van sy sestigste verjaarsdag, 203-216. Pretoria: NG Kerkboekhandel.

Vos, C J A 1996. Die volheid daarvan I: Homiletiek uit 'n hermeneutieskommunikatiewe perspektief. Pretoria: RGN.

Vos, C J A \& Pieterse, H J C 1997. Hoe lieflik is u woning. Pretoria: RGN.

Webber, R E (ed) 1994. The services of the Christian year: The complete library Christian worship, Vol 5. Star Song Publishing Group.

Wegman, H A J 1985. Christian worship in East and West: A study guide to liturgical history. Originally published in Dutch as Geschiedenis van de Christelijke Eredienst in het Westen en in het Oosten, 1976. Hilversum: Gooi en Sticht. English tr by G W Lathorp. New York: Pueblo Publishing.

Westerhoff, J H \& Willimon, W H 1980. Liturgy and learning through the life cycle. New York: The Seabury Press.

White, J F 1989. Protestant worship: Traditions in transition. Louisville, KY: John Knox.

White, J F 2000. Introduction to Christian worship, 3rd ed, revised and expanded. Nashville, TN: Abingdon Press.

Zerfass, R 1974. Praktische Theologie als Handlungswissenschaft, in Klostermann, F \& Zerfass, R, Praktische Theologie heute. München: Grünewald. 